\title{
Depositing Catalyst Layers in Polymer Electrolyte Membrane Fuel Cells: A Review
} Austin Strong ${ }^{1}$, Courtney Thornberry ${ }^{2}$, Shane Beattie ${ }^{2}$, Rongrong Chen ${ }^{1}$, Stuart R. Coles $^{2}$

${ }^{1}$ Richard Lugar Center for Renewable Energy, IUPUI, Indianapolis, IN 46202-5160

${ }^{2}$ WMG, High Value Manufacturing Catapult, University of Warwick, Coventry, UK CV4 $8 A L$

\section{ABSTRACT}

Fuel cell technology continues to advance and offers to be a potentially promising solution to many energy needs. Of particular interest are manufacturing techniques to improve performance and decrease overall cost. For catalyst deposition on the Membrane Electrode Assembly (MEA) there are a number of techniques that have been used in the past decades. This paper aims to review many of these main techniques that have been published to show the wide variety of catalyst deposition methods.

\section{Table Caption List}

Table $1 \quad$ Description of catalyst loading levels

Table 2 Catalyst loadings of main methods for MEA manufacture

\section{Figure Captions List}

Fig. 1 Schematic of electrode preparation processes for both (a) the conventional method and (b) the decal transfer method [23]

Fig. 2 The dry production technique for PEFC and DMFC MEAs [27]

Fig. 3 A visual comparison of the three main electrode manufacturing methods. [36]

Fig. $4 \quad$ MEA fabrication technique utilizing slot die coating [37]

Fig. 5 Schematic of electrophoresis deposition process for preparation of MEA [84]

Fig. 6 Schematic illustration of triple phase boundary [86]

Fig. 7 Schematic of electrospray deposition of Pt/C suspensions (top) and diagram of the electrospray process from needle to substrate space (bottom) [92]

Fig. 8 Schematic of electrospinning process that produces polymer nanofibers [98]

\section{INTRODUCTION}

Fuel cells are becoming an increasingly popular source of power due to their ability to generate continuous power with little or no emissions [1]-[4]. Some popular applications include backup power for telecommunications systems, data centers, automobiles, public transit, aircraft, space vehicles, and power for remote locations [5][7]. As the industry grows there is a need to reduce the cost of manufacturing, specifically for the PEM fuel cell, which is the current leading technology for automotive 
applications. There are several manufacturing components in a PEM fuel cell. The US Department of Energy has classified them into four main subsystems, separate from hydrogen storage:

1. The cell stack

2. The balance-of-plant

3. Power conditioning

4. System controls

Each subsystem has different manufacturing challenges. Approximately $50 \%$ of the manufacturing costs are embedded in the cell stack. This includes the Membrane Electrode Assembly (MEA) which contains the catalyst, catalyst layers, gaskets, bipolar plates, reactant manifolds (internal/external), cell stack assembly and quality assurance [8].

Costs are contributed to both material as well as manufacturing processes. One of the biggest challenges in driving down cost is in the process during which the catalyst layer is applied. Various deposition methods, like ink jet printing, vapor deposition, physical deposition, and semiconductor processing offer alternative solutions that may aid in this challenge for the manufacturing of MEAs [9]. By finding an optimal method, both the cost of process and material can be addressed in the fuel cell manufacturing process. Some challenges of manufacturing include: improving the reproducibility of the process, the speed of the process, durability of the MEA, and reduction of the overall catalyst loading [7], which will be discussed next.

The approach to reducing catalyst loading is two-fold; utilize platinum more effectively to allow for lower platinum loadings and/or to use alternative catalyst materials. A large amount of research has been focused on the catalyst materials that use less platinum. There has also been a tremendous amount of research on the methods for depositing a catalyst layer[10]-[12], however the problem still remains as to how to manufacture MEAs consistently, at low cost, and at commercial scale.

The purpose of this review is to highlight the possible array of catalyst deposition methods and trace how and why they evolved. An understanding of how deposition methods have changed to overcome challenges, and where they can go in the future will allow for greater development in the future.

Where appropriate, catalyst loadings have be converted to the units of $\mathrm{mg}_{\mathrm{Pt}} \mathrm{cm}^{-2}$ in order to obtain a realistic comparison between deposition methods. They have also been classified into groups so that the reader can gain perspective on the relative loadings in Table 1.

Table 1: Description of catalyst loading levels

\begin{tabular}{|c|c|}
\hline Description & $\begin{array}{c}\text { Catalyst loading } \\
/ \mathrm{mg}_{\mathrm{Pt}} \mathrm{cm}^{-2}\end{array}$ \\
\hline Very Low & $<0.01$ \\
\hline Low & $0.01-0.1$ \\
\hline Moderate & $0.1-1$ \\
\hline High & $1-10$ \\
\hline Very High & $>10$ \\
\hline
\end{tabular}

FC-15-1033 


\section{RESULTS AND DISCUSSION: A REVIEW OF THE LITERATURE CATALYST POWDER-BASED METHODS}

This section will discuss various powder-based methods for catalyst deposition in a PEMFC MEA.

\section{Teflon Bonded Catalyst Layers}

This was one of the first methods for depositing catalyst layers and was used during the Gemini space program (1962-1966). In this method, unsupported platinum particles were mixed with PTFE particles and hot-pressed onto the electrolyte membrane. This method requires a high $\left(4 \mathrm{mg}_{\mathrm{Pt}} \mathrm{cm}^{-2}\right)$ platinum loading, making it a non-ideal solution [13].

\section{Brush Coating a Catalyst Coated Membrane}

Brush coating a catalyst coated membrane is a technique that applies catalyst powder in an ethanol solution directly to the electrolyte membrane. This technique emerged in 1992 when the catalyst ink was painted onto the membrane and held in place by a vacuum table[14]. It has also been researched for use in Direct Ethanol Fuel Cells (DEFCs) and Direct Methanol Fuel Cells (DMFCs)[15]-[17]. The technique has also evolved to use spraying rather than hand painting [17], [18]. Hsu et al. developed a method of pretreating the Nafion film causing it to swell for catalyst deposition by spraying or blade deposition. Normally, this swelling can be problematic, but the method developed was able to address these issues. This showed good MEA performance later on, which eliminating the need for a vacuum table to hold the membrane in place during catalyst deposition [18]. While the processes vary significantly, applying catalyst mixtures directly on the membrane became the foundation for many methods of depositing catalyst layers.

\section{Brush Coating a Decal to Transfer}

The decal transfer method also emerged in 1992. In this method, the catalyst layer is applied to a substrate, then dried and hot pressed onto the electrolyte membrane. The substrate is then peeled off and the catalyst layer remains bonded to the electrolyte [19]. Decal transfer was improved with the discovery of thermoplastic forms of the Nafion membrane. The forms allowed the membrane to withstand the heat and pressure during processing [20]. The technique has also been applied for use in DMFCs [16], [17], [21]-[23]. Using heat and pressure to bond the catalyst layer with the electrolyte has become fundamental to a number of techniques, a schematic is shown in Figure 1. 

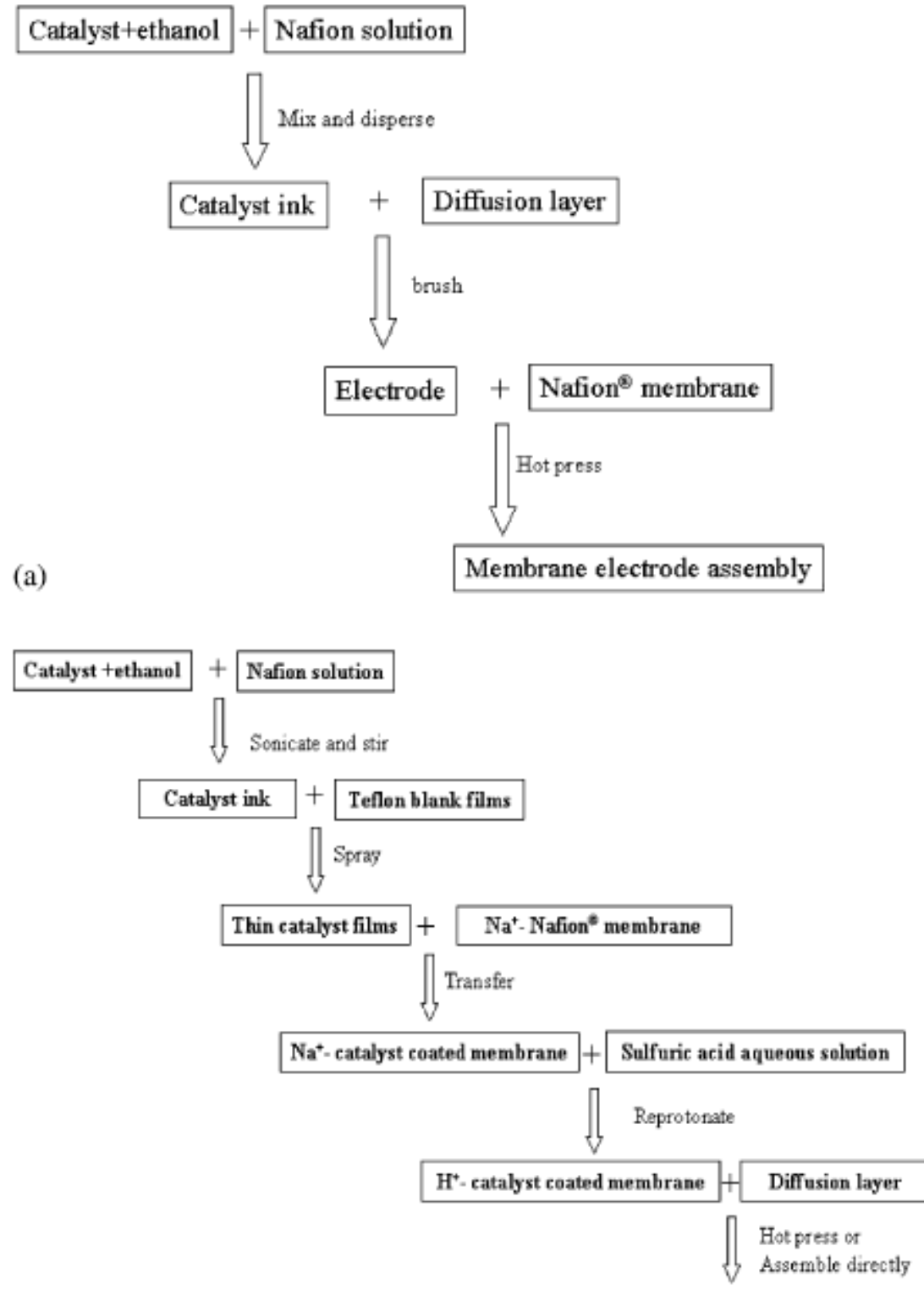

(b)

Membrane electrode assembly

Figure 1: Schematic of electrode preparation processes for both (a) the conventional method and (b) the decal transfer method [23]

\section{Screen Printing a Catalyst Slurry}

Screen printing is first reported in the literature in 1995, when Wilson et al. printed catalyst layers on Nafion membranes in the tetrabutylammonium form. In 1998 Kim et al. used the screen printing method, but used a membrane in the sodium form [24]. Chun et al. also used screen printing in their impregnation method [25]. In 2004, $\mathrm{Ihm}$ et al. further advanced the screen printing method by attaching the membrane to gasket material prior to printing [26]. This served to suppress the swelling effect due to the hydration of Nafion. Adding gasket material also improved issues with gas leakage, 
performing better than a membrane that was screen printed without gasket material [26]. In 2007, Rajalakshmi et al. combined the screen printing method with the decal transfer method, printing onto a decal transfer substrate[27]. The distribution of platinum was also analysed and it was found to be uniform with interfacial resistance decreasing by $50 \%$ using this combined method. The reduced resistance helps maintain higher current while the cell is being discharged [27].

\section{Dry Powder}

The dry powder, cold rolling process was first created by the DLR group in Stuttgart. In 1995 they were able to create MEAs using a dry powder mixture of Nafion, PTFE, and platinum-coated carbon black. A cold rolling process was used to laminate gas diffusion electrodes on both sides of a Nafion membrane [28]. In 1998 the process was automated by making it a gravity-fed system and perfecting the rolling process [29]. Another report showed that the Nafion powder could be removed, enabling the process to be fully automated using a slot nozzle and nitrogen gas to blow the mixture onto the gas diffusion membrane or directly onto the Nafion membrane [30]. That work also described the creation of a hot rolling process to make the MEA. By 2002 the process and MEA components were optimized so that the electrochemical results from MEAs produced by this process were promising[31]. A technique for dry production is shown in Figure 2.

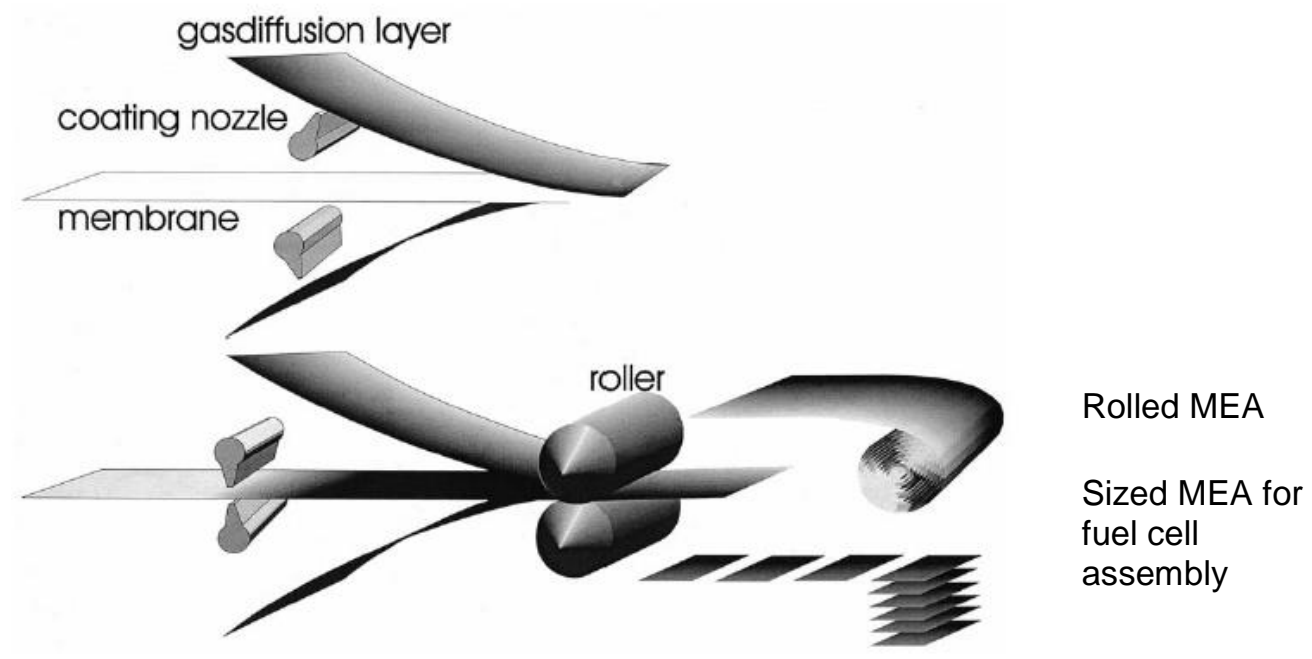

Figure 2- The dry production technique for PEFC and DMFC MEAs[30]

\section{Doctor Blade}

In 2002, Saab et al. were able to use the doctor blade coating method on a membrane that was in the protonated form, thus eliminating the ion exchange steps in the process or producing a MEA [32]. The addition of glycerol in the ink to improve printability was then studied. It was found that glycerol caused the ionic resistivity of the catalyst layer to be reduced by $75 \%$, while only increasing electrical resistivity by $30 \%$ [32]. In 2003, Bender et al. combined the doctor blade method with the decal transfer method, printing on to a substrate then hot pressing it onto a Nafion membrane [33]. This study found acceptable reproducibility in terms of uniform coating 
thickness. Unfortunately, this study also revealed problems with mass reproducibility (applying the same amount of catalyst) that seemed to be linked with ink evaporation and component settling. It was found that by using a water-based catalyst ink, and a Kapton substrate, a reduction in the variation in platinum loading was possible to $\pm 5 \%$. The authors present the fact that while this particular process is useful for creating MEAs in a laboratory setting, it may not have industrial application due to the time involved in each step [33].

\section{Inkjet Printing}

In 2007, Towne et al. detailed the process of using inkjet printing to produce a MEA, including the detailing of the general requirements of an ink solution used for printing with this method [34]. The process was demonstrated by printing a catalyst solution directly onto a Nafion membrane. The surface was examined to verify uniform distribution. The authors also investigated the secondary processes such as water soaking and hot pressing. By printing a MEA with a loading of $0.2 \mathrm{mg}_{\mathrm{Pt}} \mathrm{cm}^{-2}$, a power density of $154 \mathrm{~mW} \mathrm{~cm}^{-2}$ was achieved. A comparable commercial MEA loaded with 0.3 $\mathrm{mg}_{\mathrm{Pt}} \mathrm{cm}^{-2}$ was shown to produce a power density of $167 \mathrm{mWcm}^{-2}$ [34]. Another study in 2007, Taylor et al., used inkjet printing to print catalyst layers onto carbon cloth using a loading of $0.51 \mathrm{mg}_{\mathrm{Pt}} \mathrm{cm}^{-2}$ [35]. This showed little difference in performance versus hand painted MEAs. However, under ultra-low platinum loading of $0.021 \mathrm{mgt} \mathrm{cm}^{-2}$, the printed MEA produced $17.6 \mathrm{~W} \mathrm{mg}^{-1} \mathrm{Pt}$. The ability of inkjet printing to create a graded structure of varying catalyst/Nafion ratios was also demonstrated by Taylor et al. [35]. In 2009, Saha et al. examined the morphology of a MEA printed onto Nafion and found it to be more uniform at lower platinum loading. Further durability testing found no significant decrease in performance after 18 hours of discharging at $300 \mathrm{~mA} \mathrm{~cm}^{-2}$ [36].

In 2012, Malevich et al. investigated the effect of printing geometrically patterned catalyst layers onto Nafion membranes for MEAs [37]. It was discovered that the patterns had a profound effect both on electrochemically active surface area, and in the polarizations due to activation and mass transport [37]. Also in 2012, Yazdanpour et al. investigated the effects of the hot-press assembly parameters (temperature, pressure, and time). They found that cell performance decreased with pressure, temperature, and time. They predicted an optimum hot press process of 800 psi at 100 ${ }^{\circ} \mathrm{C}$ for 3 minutes. Using these conditions, an MEA was prepared by printing onto Nafion and was found to have higher electrochemically active surface area than a MEA prepared using the decal transfer method with identical platinum loading [38].

\section{Scrape Method}

There are three electrode manufacturing methods described by Wu et al. (2009) as being mature enough to sufficiently control electrode thickness and weight: rollerapplied method, scrape-applied method and spraying applied method. Wu et al. (2009) successfully used the scrape method for fuel cell manufacturing. This method involves a continuously moving carbon paper electrode coated with catalyst ink. As the carbon paper moves under the scraper, the thickness is limited by the scraper and the surface tension of the ink maintains the thickness while it dries uniformly [39]. A visual comparison of the three main electrode manufacturing methods is shown in Figure 3. 


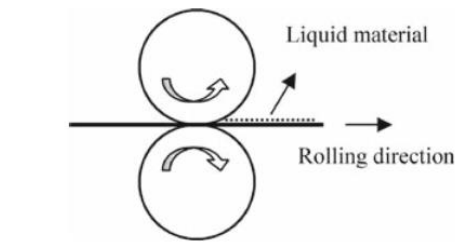

Roller-applied method

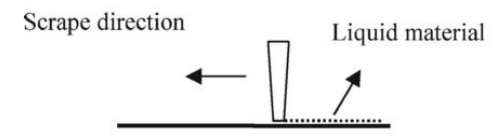

Scrape-applied method

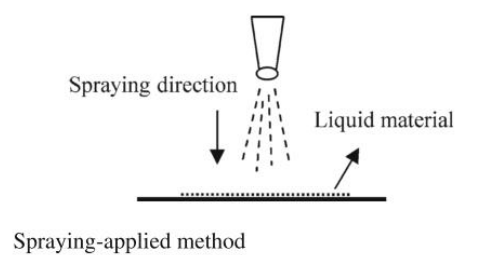

Figure 3: A visual comparison of the three main electrode manufacturing methods.

[39]

\section{Slot Die Coating}

Ding et al.(2012) investigated using a slot die to deposit a liquid layer onto gas diffusion layers. During single cell testing, the MEAs were found to have similar results as traditionally produced MEAs. The authors also identified several problems with this production technique and worked to mitigate them. Through experiments, the authors found that using a microporous layer and forced convection to reduce ink penetration. Additionally, using a pressing operation improves uniform coating thickness [40]. Figure 4 shows the MEA fabrication technique utilizing slot die coating.

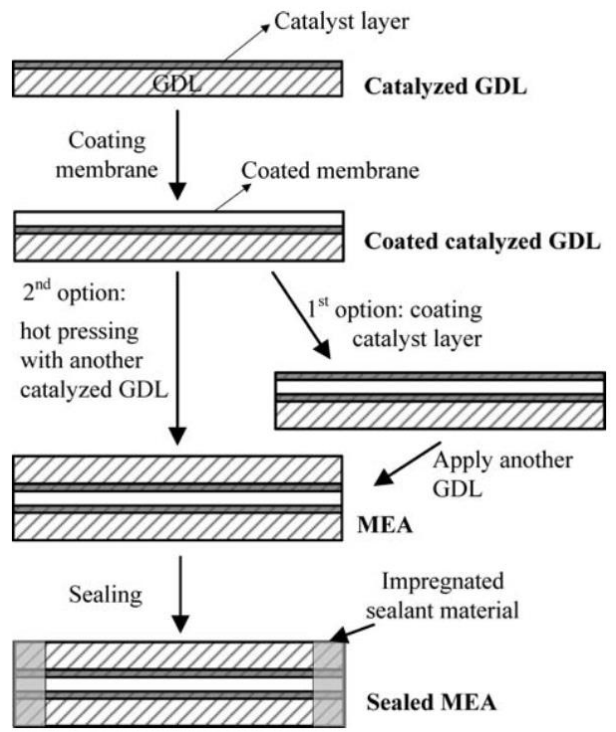

Figure 4: MEA fabrication technique utilising slot die coating [40]

FC-15-1033

Courtney Thornberry 


\section{VAPOUR BASED METHODS \\ Plasma Sputtering}

Platinum sputtering was used as early as 1969 with respect to electrochemical cells [41]. However, there is no record that platinum was sputtered onto fuel cell electrodes until 1987. At this time, a layer of platinum was sputtered onto Teflon-bound electrodes. Half-cell tests were performed and this method was found to be very promising, offering only a slightly decreased performance versus a conventional electrode with twice the platinum loading. This was attributed to superior performance of the oxygen reduction reaction (ORR) [42].

In 1988, Ticianelli et al. performed a thorough investigation to characterize how sputtered electrodes performed in a cell. They found that by sputtering a coating of platinum onto the surface of low $\left(0.4 \mathrm{mg}_{\mathrm{Pt}} \mathrm{cm}^{-2}\right)$ loaded electrodes, current densities could be produced that rivaled conventional cells. The authors found that at a current density of $1 \mathrm{~A} \mathrm{~cm}^{-2}$, the sputtered electrodes produced twice the power of conventional electrodes. The sputtered electrodes were also found to be stable over time, at several different discharging current densities [43]. In 1993, Mukerjee et al. performed an indepth investigation of how a sputtered catalyst layer improved the kinetics of oxygen reduction. This study revealed better platinum exposure, and lower activation losses. These led to significant improvements in current density [44].

\section{Plasma Sputtering}

In 1997, Hirano et al. made a significant step when they investigated sputtering platinum onto an electrode that had no catalyst content. It was illustrated that sputtered electrodes with platinum loadings as low as $0.1 \mathrm{mg}_{\mathrm{Pt}} \mathrm{cm}^{-2}$ could still produce high current densities and produced a maximum power density of $714 \mathrm{~mW} \mathrm{~cm}^{-2}$. However, the performance was still slightly less than a conventional electrode with 0.4 $\mathrm{mg}_{\mathrm{Pt}} \mathrm{cm}^{-2}$. This was attributed to higher ohmic losses in the sputtered electrodes [45].

The process evolved in 1999 when Cha and Lee sputtered platinum directly onto a Nafion membrane, Both DC and RF sputtering techniques were used, with appropriate power and pressure to each system. The samples studied in the work were not differentiated by specific sputtering technique in the result, indicating that the technique was considered irrelevant to subsequent sample measurements. Sputtering directly onto the membrane created with a platinum loading of $0.04 \mathrm{mg} \mathrm{cm}_{\mathrm{Pt}} \mathrm{cm}^{-2}$ generated a specific power of nearly $6 \mathrm{~W} \mathrm{mg}^{-1} \mathrm{Pt}$. A conventional electrode with a

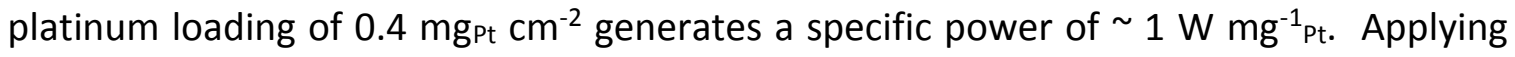
an ink solution of Nafion and carbon between layers of sputtered platinum was also found this to improve performance [46].

In 2002, Huag et al. directly compared the two processes, sputtering platinum onto electrodes and sputtering platinum onto Nafion. It was discovered that a MEA created by sputtering platinum onto the gas diffusion layer had higher current at identical potential as an MEA created by sputtering platinum onto Nafion. They also attempted to create a three-dimensional reaction zone that contained Nafion, carbon, and platinum. They found that layering of carbon and Nafion between sputtered layers of platinum on gas diffusion layers was not beneficial to the performance of a cell, likely due to the thickness of the carbon/Nafion layers [47]. The same group also investigated 
sputtering layers of ruthenium between layers of platinum to improve the tolerance of carbon monoxide. The separation of ruthenium layers was found to double the tolerance of carbon monoxide compared to traditional platinum-Ruthenium alloys [48].

In 2002, major progress was made when sputtering was shown to shown to have tremendous potential for lowering platinum loadings. In this instance, a sputtered cell produced $60 \%$ of the power density of a conventional cell, with much lower catalyst loadings. A conventional cell, defined as an ink-based method of fabrication, contained 10 times the amount of platinum catalyst that was in the sputtered cell. Sputtering was also shown to be durable in several qualitative tests of the surface, particularly in longer term performance testing which did not show any performance degradation [49].

\section{Very High Frequency (VHF) Sputtering}

In 2004, the process evolved when Brault et al. used VHF inductive sputtering to deposit platinum onto gas diffusion layers for the first time. This was done to obtain a better understanding of the deposition process, specifically to understand catalyst penetration in the electrodes. Platinum was deposited at a loading of $0.08 \mathrm{mg}_{\mathrm{Pt}} \mathrm{cm}^{-2}$ to a depth of $2 \mu \mathrm{m}$, resulting in a specific power of $5 \mathrm{~W} \mathrm{mg}^{-1}{ }_{\mathrm{Pt}}[50]$.

\section{Radio Frequency (RF) Sputtering}

In 2005, Gruber et al. demonstrated the ability to obtain ultra-low platinum loadings, depositing $5 \mu \mathrm{g} \mathrm{Pt}^{-2}$. This loading level in both anode and cathode achieved a power density of $124 \mathrm{~mW} \mathrm{~cm} \mathrm{~cm}^{-2}$. The authors also demonstrated that power density could be increased by sputtering chromium or vapor depositing palladium onto a $25 \mathrm{~nm}$ platinum layer [51]. In 2007, applying thin film layers between the electrode and the layer of platinum was attempted. It was found that a sub-layer of chromium, palladium, or silicon-based polymers helps to distribute the platinum more uniformly, and further increase power density. The authors also investigated the effect of oxygen plasma treatment of commercial electrodes and found improved power densities by exposing increased catalyst sites[52].

In 2005, Caillard et al. studied the diffusion of platinum into gas diffusion layers and found that plasma conditions influenced the diffusion process, indicating a need to study the plasma control parameters on fuel cell performance [53]. Huang et al. then investigated the effect of RF power and vacuum pressure on the electrochemical properties and performance in the activation region. The authors found increased RF power led to increased deposition rates. The increased speed of deposition at a higher energy, however, caused damage to the crystalline structures leading to higher kinetic resistance. The optimal electrode structure was obtained at RF power of $100 \mathrm{~W}$. The authors also tested pressure, and found that decreasing pressure increased the deposition rate. They found that $10^{-3}$ Torr had a higher surface area and considerably lower kinetic resistance that pressures of $10^{-2}$ and $10^{-4}$ Torr. The authors concluded that at this platinum loading, the sputtering pressure had a more significant impact than RF power [54]. In 2008, Rabat and Brault investigated sputtering alternating layers of platinum and platinum /carbon onto a Nafion membrane. This method was found to increase the open circuit potential by $12 \%$, as compared to a commercial MEA of identical platinum loading [55]. 


\section{Transformer Coupled RF Sputtering}

A variation of RF sputtering process is transformer coupled RF sputtering. It is unclear when this process evolved and little literature was found regarding the origin and history of transformer coupled RF sputtering. However, the method is worth noting due to promising recent results. In 2011, a transformer coupled RF sputtering method was used to deposit a pure palladium anodic catalyst layer and a $10 \%$ platinum / palladium catalyst layer for a catalyst electrode. With total loadings of $20 \mu \mathrm{g}_{\mathrm{Pd}} \mathrm{cm}^{-2}$ and $1 \mu \mathrm{g}_{\mathrm{Pt}} \mathrm{cm}^{-2}$, a specific power of $12.5 \mathrm{~kW} \mathrm{~g}^{-1} \mathrm{Pd}$ and $250 \mathrm{~kW} \mathrm{~g}^{-1} \mathrm{Pt}_{\mathrm{t}}$ was achieved [56].

\section{Magnetron Sputtering}

In 2006, Wan et al. demonstrated the use of magnetron sputtering for depositing the catalyst layer. Magnetron sputtering uses a magnetic field to control the plasma and focus it onto the target, in this case it is unclear if the plasma was generated by DC or RF excitation; it is known that the pressure of the deposition occurred on the order of $10^{-3}$ Torr with a target current of $0.25 \mathrm{~A}$. An advantage of this method is that it allows for shorter sputtering times, which ranged from 30 to 470 seconds. In their study, the authors investigated the effect of bias voltage, pressure, and sputtering time on cell performance and found a direct correlation to catalyst porosity, thickness and loading. They also demonstrated the ability to deposit multiple layers of platinum using this method [57].

In 2008, Yoo et al. further investigated the effect of sputtering pressure on fuel cell performance. They found that high pressure of approximately $200 \mathrm{mTorr}$ produced catalyst layers with significantly higher electrochemically active surface area, leading to power density of $420 \mathrm{~mW} \mathrm{~cm}^{-2}$ and a specific power of $10.5 \mathrm{~W} \mathrm{mg}^{-1}$ [58]. Also in 2008, Kim et al. expanded the three dimensional reaction zone by sputtering platinum onto a layer of Vulcan XC-72 and carbon nanotubes. The electrochemically active surface area was increased, and a catalyst layer with this structure outperformed a screen-printed electrode with a platinum loading ten times higher. This was attributed to high mass activity and good mass transport characteristics[59].

In 2009, Cavarroc et al. used magnetron sputtering to deposit an ultra-low loading of $10 \mu \mathrm{g} \mathrm{cm}^{-2}$ with carbon particles and achieved a power density of 400 $\mathrm{mW} / \mathrm{cm}^{2}$. This corresponded to a specific power of $20 \mathrm{~kW} \mathrm{~g}^{-1} \mathrm{Pt}$, which was reported to be the highest specific power at the time [60]. In 2010, Natarajan and Hamelin evolved the layering technique to further expand the reaction zone. They sputtered differing platinum loadings on different levels, with layers of Nafion and carbon nanotubes between the platinum layers. A structure with three layers of platinum containing a total loading of $0.5 \mathrm{mgt} \mathrm{cm}_{\mathrm{Pt}} \mathrm{cm}^{-2}$ with layers of carbon nanotubes and $29 \%$ Nafion was found to be optimal [61].

\section{Decal Sputtering}

Also in 2005, Nakakubo et al. combined sputtering with a decal transfer process, creating a new evolution of the sputtering method. Platinum was sputtered onto a PTFE membrane, and was then transferred to a Nafion membrane by a hot pressing process. This technique was used to eliminate problems with cracking that developed when Nafion was placed in a vacuum. The performance of a MEA prepared by this method 
was found to be suitable, particularly for micro fuel cells because of suitable horizontal conductivity in the catalyst layer [62].

\section{Helicon RF Sputtering}

In 2007, Caillard and coworkers investigated helicon plasma sputtering to apply catalyst layers. Carbon nanofibers were grown and platinum was deposited onto the fibers. This method was shown to allow for platinum utilization four times higher than conventional electrodes with higher platinum loading [63]. In 2008, a study was performed on different carbon support layers such as Vulcan XC-72, carbon nanofibers, and the combination thereof, for the platinum layer. They also demonstrated that electrodes prepared by these methods were suitable for both the anode and cathode [64]. In 2009, significant progress was made by optimizing plasma parameters as well as Nafion and platinum content. By optimizing these parameters, they were able to load electrodes with $5 \mu \mathrm{g}$ of platinum and obtain an anodic specific power of $85 \mathrm{~kW} \mathrm{~g}^{-1} \mathrm{Pt}$, which was 100 times higher than a commercial anode with $0.5 \mathrm{mg}_{\mathrm{Pt}} \mathrm{cm}^{-2}$. The cathodic specific power at the same ultra-low platinum loading was found to be $22.5 \mathrm{~kW} \mathrm{~g}^{-1} \mathrm{Pt}$, which was approximately 26.5 times higher than the commercial electrode [65].

\section{Ion Beam in Catalyst Deposition}

Ion Beam Assisted Deposition

It is unclear when ion beams were first used for depositing coatings, however the method is reported in the literature for depositing fuel cell catalyst layers as early as 1983 [66]

\section{Dual Ion Beam Bombardment}

Dual ion beam bombardment was used for depositing fuel cell catalyst layers in 2005. It was deemed a useful method due to its ability to use one beam to roughen the surface of the substrate and a second beam to deposit catalyst particles [67]. In 2005, it was used to deposit platinum onto gas diffusion media and performance was shown to be similar to a commercial electrode [68]. In 2006, this method was employed to deposit layers of cobalt and chromium beneath the platinum. Using dual metals led to increased performance and allowed for less platinum loading on the electrodes [69]. Also in 2006, a detailed analysis using this method was performed, measuring results for various ultra-low platinum loadings. The kinetics of the oxygen reduction reaction were also studied with respect to this method of depositing the catalyst layer and it was found that a patterning method of deposition helped to mitigate transport losses in the cell and thus improving performance [70]. In 2009, further investigation was performed on catalyst layers that were deposited using this method. Degradation analysis was performed using a radical attack technique, and the dual ion beam deposited layer was found to have better durability than a commercial electrode [67].

\section{Pulsed Laser Deposition}

In 2003 , the process was developed to deposit a layer of $17 \mu \mathrm{g}_{\mathrm{Pt}} \mathrm{cm}^{-2}$ onto gas diffusion layers. Using this loading, a nearly identical performance as a commercial electrode with a loading of $0.4 \mathrm{mg} \mathrm{gt}_{\mathrm{Pt}} / \mathrm{cm}^{2}$ was achieved [71]. 


\section{ELECTRICAL PROCESSES}

\section{Electrodeposition}

Electrodeposition of platinum from chloroplatinic acid was first performed in 1894. Since then there were a number of investigations of the process and variables including substrate treatments, different acid electrolytes, and other chemicals mixed with the electrolyte. There were also studies performed that examined the appearance and growth of the platinum deposits [72]. In 1986, Itaya et al. applied a film of Nafion to glassy carbon electrodes, and performed platinum electrodeposition. They were able to deposit platinum on the surface of the electrode and through the layer of Nafion [73]. In 1992, Taylor et al. used a commercial plating bath to deposit platinum on the surface of a carbon electrode that was coated with Nafion. This method requires regions where both electrical and ionic conductivity are possible, effectively "targeting" the threephase boundary required for the catalyst to be used [74]. In 1994, Verbrugge proposed a modified method and was able use dilute platinum salt solutions to selectively deposit platinum on the surface of a carbon electrode that was coated with Nafion which was so successful it became the standard method for electrodeposition of platinum salts [75]. Ion exchange electrodeposition

In 2001, Thompson et al. suggested a method to exchange platinum cations with Nafion in solution. The solution was then applied to an electrode and electroreduced in sulfuric acid. This deposited the platinum very near to the surface of the electrode, and also changed the Nafion back to proton form [76].

\section{Pulsed electrodeposition}

In 1998, Choi et al. compared pulse electrodeposition with DC electrodeposition and found it favorable because the size of platinum particles could be controlled by use of the electrical duty cycle and current density. They were able to deposit platinum particles smaller than $50 \mathrm{~nm}$. They found that brushing the surface of the electrode with carbon and PTFE was favorable because it provided more sites for nucleation. The authors also investigated the parameters of the pulse electrodeposition process including duty cycle (on time and off time), and current density. After optimization of the process, MEAs prepared by pulse electrodeposition were found to perform better than those prepared by DC electrodeposition [77]. Kim and Papov used a similar method and were able to limit platinum particle size to less than $5 \mathrm{~nm}$ whilst using a $75 \%$ platinum on carbon source, and the catalyst layer catalyst layer was only $50 \mu \mathrm{m}$ thick (Kim \& Popov, 2004). In the same year, the authors performed a detailed analysis of their new pulse electrodeposition method versus direct current electrodeposition and found the performance to be favorable. They also performed further investigation of the pulse electrodeposition parameters [79].

In 2006, Lee et al. modified this method to deposit platinum from a solution of platinum chloride. It was deposited onto a carbon paper electrode, which had a hydrophilic layer. The hydrophilic layer consisted of Nafion (in sodium form), and carbon black (Vulcan XC-72). They showed that with a platinum loading of $0.025 \mathrm{mg} \mathrm{cm}_{\mathrm{Pt}}^{-2}$ on the anode, they could duplicate a conventional MEA with a loading of $0.3 \mathrm{mg}_{\mathrm{Pt}} \mathrm{cm}^{-2}$. This was attributed to high catalyst utilization due to the deposition of platinum only happening at the three-phase reaction zone [80]. 
In 2007, Ayyadurai et al. tested the effect of hydrophilic agents on the pulse electrodeposition process. The authors adding wetting agents to the electrodeposition mixture and found this to increase the rate of platinum deposition, while maintaining uniformity of deposition and controlling particle growth. They were also able to limit the depth of deposition to less than $2 \mu \mathrm{m}$ [81].

In 2008, Rajalakshmi and Dhathathreyan further investigated the various parameters of the pulse electrodeposition process, including duty cycle, Nafion content, and current density. By optimizing these factors, the ohmic resistance was lowered significantly to $0.00076 \mathrm{~m} \Omega \mathrm{cm}^{-2}$ [82].

In 2009, Martin et al. characterized the depositions of platinum nanoclusters using physical and chemical methods. They found that the depth of deposited platinum was limited by the diffusion of the precursor. They illustrated the ability to use electrodeposition to prepare electrodes with platinum loading less than $0.05 \mathrm{mg}_{\mathrm{Pt}} \mathrm{cm}^{-2}$ [83].

\section{Current Modulated Electrodeposition}

A change to the pulse electrodeposition method was proposed by Wei et al. in 2007. Seeing problems with current rise and fall during normal pulse electrodeposition, the authors used current modulation to control the duty cycle and peak current density. While this method did show up to $69 \%$ platinum utilization, there were still drawbacks including hydrogen evolution and large particle sizes [84].

\section{Ultrasonic Electrodeposition}

The electrodeposition method evolved again in 2008 when Pollet applied ultrasound to a pulsed galvanostatic electrodeposition bath. In this study, an MEA with a catalyst layer prepared by this method was shown to have improved performance over silent pulse galvanostatic electrodeposition. It is thought that this method acts as a "reducing agent" to help form particles with better catalytic properties [85], [86].

\section{Electrophoresis}

In 2004, Moriwaka et al. proposed the use of electrophoresis to deposit catalyst layers. This method took advantage of surface charges on particles, and was useful because it could be applied to many different membrane materials. It was also advantageous because it eliminated the hot pressing step that is common to many MEA fabrication methods. After optimizing the electrophoresis process for their membrane and catalyst mixture, they examined the catalyst layer. They found more uniform deposition of particles, and a thinner catalyst layer than an MEA prepared by the decal method. It was also found to utilize $56 \%$ of the deposited platinum, and to perform better in single cell discharge testing than a hot pressed MEA [87]. By 2006, Munakata et al. had studied the variables of the electrophoretic deposition process including composition of the catalyst mixture including Nafion content, electric field intensity, and deposition time on the performance of the MEA. They were able to achieve a $76 \%$ platinum utilization rate [88]. In 2007, the same group performed a detailed investigation of the MEA and found that electrophoresis resulted in a larger electrochemically active surface area than the decal method [89]. 


\section{Electrophoretic electrodeposition}

In 2011, an electrophoresis deposition method was proposed by $\mathrm{Yu}$ et al. This method is a combination of electrophoresis and electrodeposition. It uses an electric field to control the size of the platinum particles deposited by electrodeposition. They succeeded in depositing platinum nanoparticles onto the electrode, and controlling the size to 3-4 $\mathrm{nm}$. They also found that using a $25 \%$ duty cycle for 10 minutes led to a peak specific current of $440 \mathrm{~mA} \mathrm{mg} \mathrm{Pt}^{-1}$ [90]. In 2013, Adilbish et al. further investigated this technique. They varied the duty cycle and found that a $25 \%$ duty cycle (on a 1 minute scale) yielded the best surface morphology of platinum clusters. After optimizing the duty cycle, they investigated the effect of time on the deposition of platinum on the electrode. They also analyzed the effect of deposition time on electrochemically active surface area. They found that with time, the hydrogen oxidation activity increases, but the electrochemically active surface area decreases after ten minutes. While this technique is very new, they were able to achieve a specific power density of $3.88 \mathrm{~W}$ $\mathrm{mg}_{\mathrm{Pt}^{-1}}$ [91]. Also in 2013, Felix et al. further optimized the electrophoresis process by investigating Nafion content, $\mathrm{pH}$ level of the solution, and field strength. Single-cell testing demonstrated poor performance, but this was attributed to Nafion not being a suitable ionomer for high temperature PEMFCs [92]. Figures 5 and 6 show the schematic of the electrophoresis deposition process for the MEA and an illustration of the triple phase boundary from this technique, respectively.

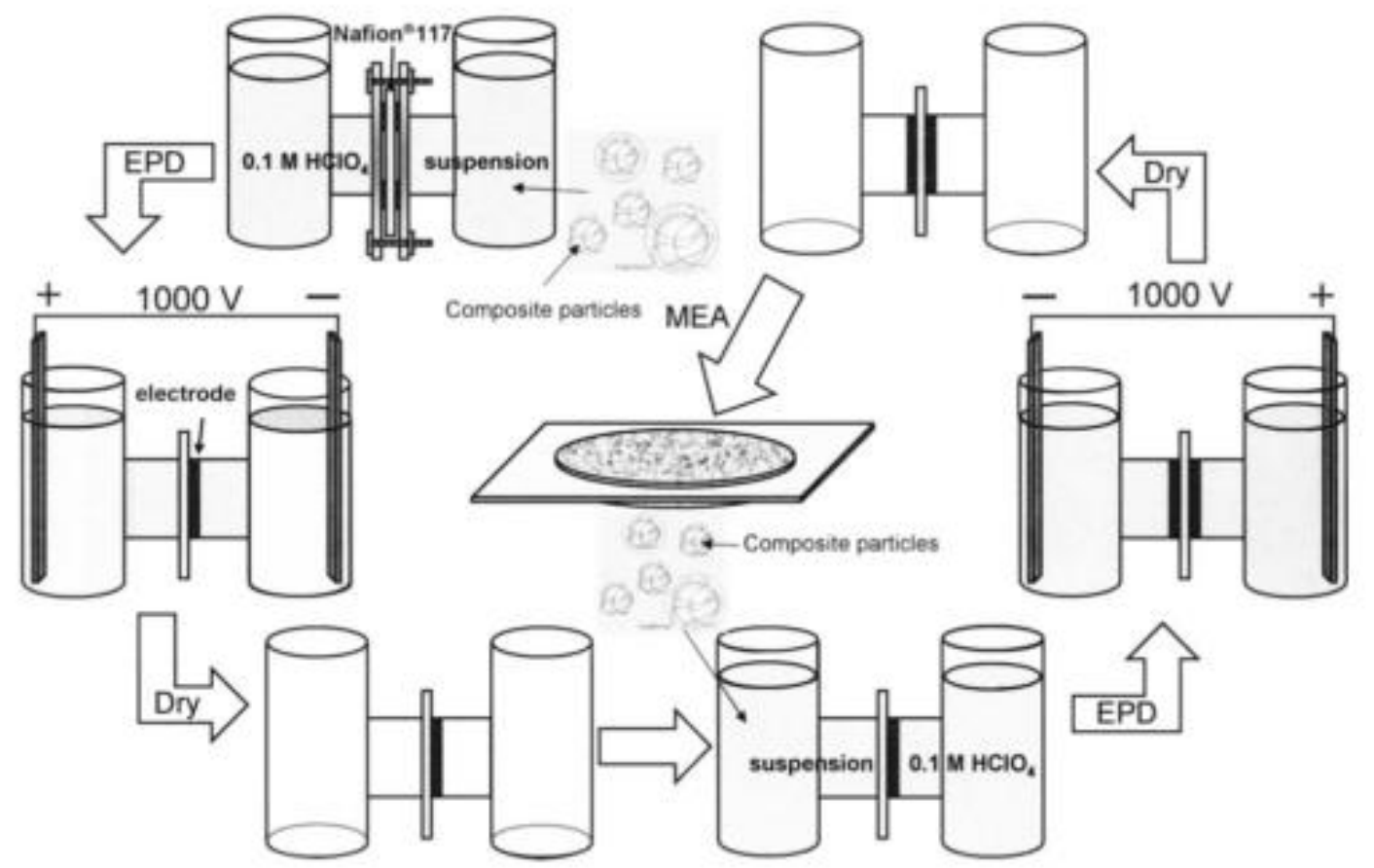

Figure 5: Schematic of electrophoresis deposition process for preparation of MEA [87]

FC-15-1033 


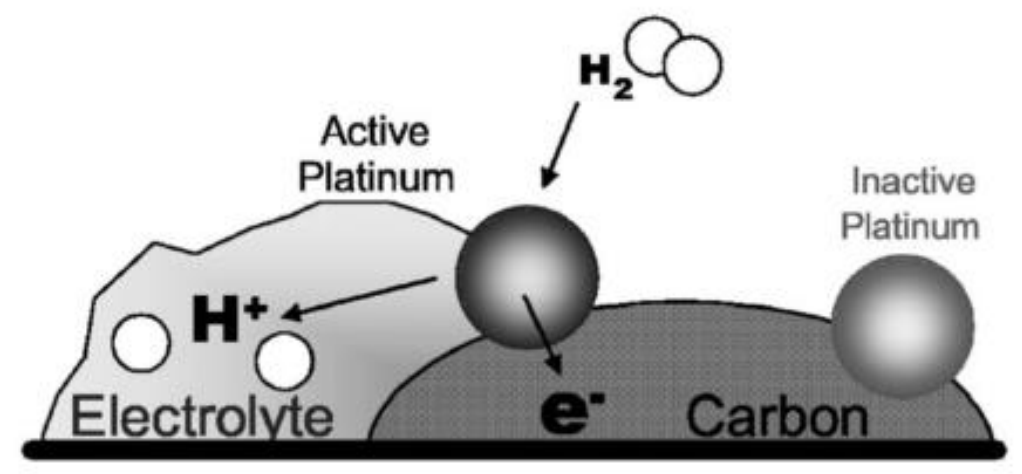

Figure 6: Schematic illustration of triple phase boundary [89]

\section{Electrospray}

In 2005, Baturina and Wnek evaluated the use of electrospraying for use in PEFCs. They sprayed the catalyst directly onto the electrolyte membrane, and were able to obtain a current density of $1 \mathrm{~A} \mathrm{~cm}^{-2}$ during single cell testing [93]. In the same year, Benitez et al. used electrospraying to apply a catalyst layer to the gas diffusion layer. They then compared the electrospray technique with traditional spraying and platinum impregnation methods, as well as a commercial MEA. The electrosprayed MEA was found to have the highest current values at identical platinum loadings. The MEAs were examined using surface methods and found to have more uniform platinum distribution, which led to the higher results [94].

In 2007, Chaparro et al. then investigated the effect of a high temperature solvent (butylacetate, ethanol, and glycerol) instead of isopropanol on MEA performance. This was done because using isopropanol appeared to cause changes to the Nafion ionomers in the electrospray solution because it evaporates at a low temperature. Using a high temperature solvent they were able to increase mass specific area to $101 \mathrm{~m}^{2} \mathrm{~g}^{-1}$. At a cathode loading of $0.3 \mathrm{mg}_{\mathrm{Pt}} \mathrm{cm}^{-2}$, they showed slightly better performance in low current density than a commercial MEA with a cathode loading of $0.5 \mathrm{mg}_{\mathrm{Pt}} \mathrm{cm}^{-2}$. However, the electrosprayed MEAs had higher mass transport losses in high current density. The stability of an electrosprayed MEA was also investigated and found to have a decay rate of 7 microvolts per hour over 600 hours, at a current demand of $500 \mathrm{~mA} \mathrm{~cm}^{-2}$ [95].

In 2010, Martin et al. optimized the control parameters of the electrospray process, the Nafion content of the ink, and the hot press process after spraying. This led to a very developed fractal structure and high performance [96]. The same year, they also optimized the operating conditions for cells using an MEA prepared with this technique. With a platinum loading of $0.012 \mathrm{mg}_{\mathrm{Pt}} \mathrm{cm}^{-2}$ on the cathode, they were able to attain a cathode specific power of $20 \mathrm{~kW} \mathrm{~g}^{-1} \mathrm{Pt}$ [97].

In 2012, Martin et al. used improved gas diffusion layers with better water management and were able to achieve higher results. Using a platinum loading of 0.01 $\mathrm{mg}_{\mathrm{Pt}} / \mathrm{cm} 2$ and achieved a specific power in the range of $30-35 \mathrm{~kW} / \mathrm{g}_{\mathrm{Pt}}$ [98]. Figure 7 shows the schematic of this technique as well as the diagram of the process from needle to substrate space. 

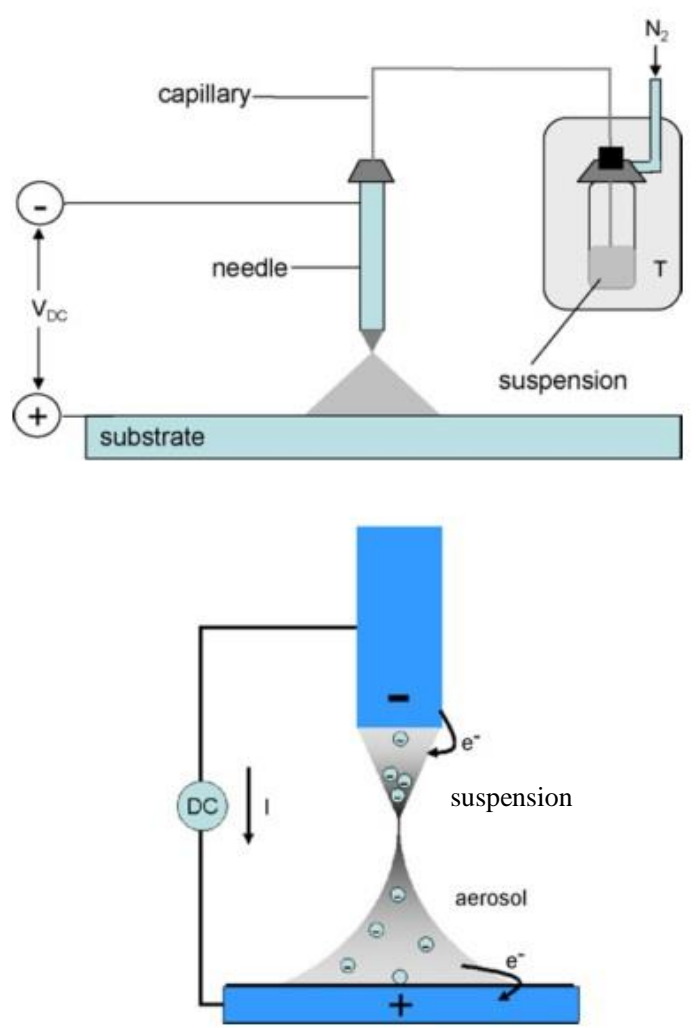

Figure 7: Schematic of electrospray deposition of Pt/C suspensions (top) and diagram of the electrospray process from needle to substrate space (bottom) [95]

\section{Electrospinning}

Zhang et al. started investigating the use of electrospinning to deposit a mixture of catalyst, Nafion, and poly(acrylic acid) onto aluminum foil. The fibers were then annealed and hot pressed it to a Nafion membrane. During single cell testing, the electrospun MEA generated $44 \%$ more power at high humidity conditions than a decal MEA of identical platinum loading. Under low humidity conditions, this difference was much greater, with the electrospun MEA generating $129 \%$ more power than the decal MEA [99].

The same year, Zhang and Pintauro did more diagnostic testing on MEAs produced by electrospinning the catalyst mixture. They found that the morphology remained intact after hot pressing, and also quantified the electrochemically active surface area of their MEA at $114 \mathrm{~m}^{2} \mathrm{~g}^{-1} \mathrm{Pt}$, nearly twice that of a MEA produced by the decal transfer method with the same platinum loading. They also reported a mass specific activity of $0.23 \mathrm{~A} \mathrm{mg}^{-1} \mathrm{Pt}$ at a potential of $0.9 \mathrm{~V}$, which was one of the highest in literature. This also matched a commercially nanostructured material. [100].

In 2013, Sighter et al. investigated the use of electrospinning to produce a platinum nanofiber mat that was transferred to a Nafion membrane by the decal transfer method. They found that at a platinum loading of $0.1 \mathrm{mg}_{\mathrm{Pt}} \mathrm{cm}^{-2}$ the electrospun MEA had $30 \%$ higher current density and $62 \%$ higher electrochemical surface area as compared to an MEA that was prepared by ultrasonic spraying with the same platinum

FC-15-1033 
loading [101]. Also in 2013, Brodt et al. found that at a potential of $0.65 \mathrm{~V}$, an electrospun anode at $0.1 \mathrm{mg}_{\mathrm{Pt}} \mathrm{cm}^{-2}$ and an electrospun cathode at $0.065 \mathrm{mg}_{\mathrm{Pt}} \mathrm{cm}^{-2}$ had a $29 \%$ higher power density than a decal MEA with anode loading of $0.4 \mathrm{mg} \mathrm{cm}_{\mathrm{Pt}} \mathrm{cm}^{-2}$ and a cathode loading of $0.104 \mathrm{mg}_{\mathrm{Pt}} \mathrm{cm}^{-2}$. Additionally, they found that with electrospun anode loading of $0.059 \mathrm{mg}_{\mathrm{Pt}} \mathrm{cm}^{-2}$ and a cathode loading of $0.055 \mathrm{mg}_{\mathrm{Pt}} \mathrm{cm}^{-2}$, they could produce a power density of $906 \mathrm{~mW} \mathrm{~cm}^{-2}$, using $2000 \mathrm{sccm}$ of humidified air, at a temperature of $80{ }^{\circ} \mathrm{C}$ [102]. Figure 8 shows the schematic of the electrospinning process that produces polymer nanofibers.

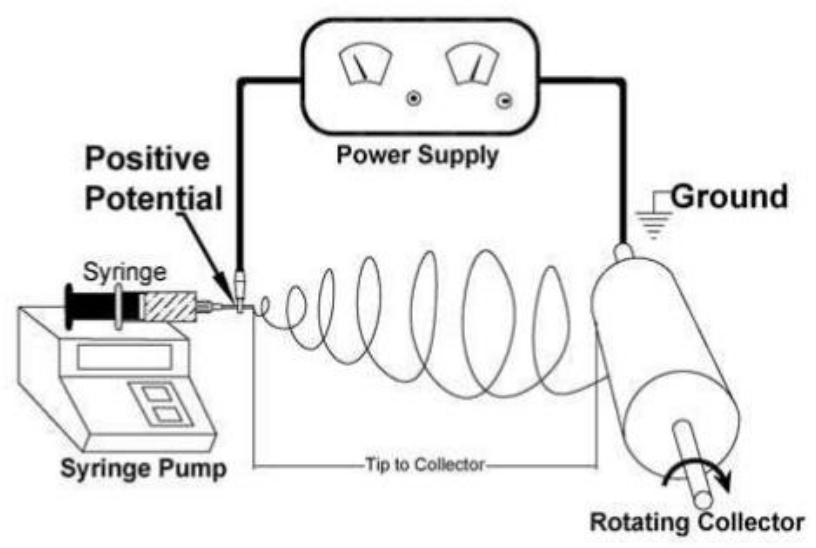

Figure 8: Schematic of electrospinning process that produces polymer nanofibers [101]

\section{ULTRASONIC SPRAY}

It is unclear when the ultrasonic spray method was first used for depositing fuel cell catalyst layers. It appears in literature in 2010 [103], although this instance reveals that the ultrasonic spray method has been commercialized by Sonotek since 1975. A patent application filed in 2009 and published in 2010 (2010/0078496) lists the use of ultrasonic spray to deposit catalyst layers for fuel cells. In 2011, this method was used by Millington et al. to deposit a catalyst layer onto gas diffusion layers. In that study, the authors compared multiple gas diffusion electrodes that were prepared by hand painting and ultrasonic spraying. The study found performance was similar at high platinum loading, but at lower platinum loading ultrasonic spray was preferential. This was attributed to the ultrasound energy preventing clogging and agglomeration of particles. A peak platinum utilization of $10.9 \mathrm{~W} \mathrm{mg}^{-1} \mathrm{Pt}$ was obtained at a loading of 50 $\mu \mathrm{g}_{\mathrm{Pt}} \mathrm{cm}^{-2}$ [104]. The same year, Huang et al. used the same method to apply a catalyst layer to Nafion membrane. The authors tuned the parameters of the spray process and were able to obtain approximately $89 \%$ platinum utilization. It was also noted during testing that the cells exhibited no limiting current behavior at very high current densities, indicating exceptional mass transport properties [105]. In 2012, Huang et al. studied the Nafion content of inks used for ultrasonic spray. The optimal amount varied with differing platinum loadings, however they found that the optimal Nafion content should not exceed $40 \%$ by weight [106]. 


\section{NANOSTRUCTURED CATALYST LAYERS}

Nanostructuring of catalyst layers has gained increasing importance as research drives platinum loadings lower and lower. One of the earliest examples of this technique was proposed by Middelmen. In 2002 he proposed a "self-assembly" method of nanostructuring. He theorized an ideal structure of platinum coated supports, perpendicular to the electrolyte surface. This would allow protons to conduct freely through perpendicular pores to the electrolyte membrane, and it would allow a direct path for electrons to conduct to the conductive gas diffusion media. He was able to manipulate materials, reaction variables, and use electric field to create this morphology [107].

Since Middelmen's work, a number of nanostructures have been designed by researchers. Many of these structures were new at the time and it is difficult to trace how the nanostructuring approach has evolved through time. In lieu of a history of the nanostructuring method a list of examples is offered. This list is not intended to be allinclusive; it is merely a sample of what types of nanostructures have been created for use in the catalyst layer of fuel cells. Readers who are interested in these methods are encouraged to research literature in this area.

- Chemical reduction of platinum onto carbon nanotubes [108].

- Chemical reduction of platinum onto a mixture of carbon nanotubes and carbon fibers to be assembled using a layer-by-layer method [109].

- Chemical reduction of platinum to in an urchin-like structure [110].

- Chemical reduction of platinum into nanoclusters [111]

- Platinum nanowires have been grown on the surface of platinum gauze [112], carbon nanospheres [113], onto the surface of gas diffusion layers [114], or used as seeds for nanoflowers [115].

- Specific crystal structures have been created [116]

\section{CONCLUSIONS}

In total, five main processes for producing the catalyst layer have been presented:

- Catalyst powder-based methods (8 processes listed)

- Vapour based methods (9 processes listed)

- Electrical processes (8 processes listed)

- Ultrasonic spray

- Nanostructured catalyst layers

The oldest methods utilise the catalyst powder-based process. Much of the literature does not give specific catalyst loading for these methods, but Teflon bonded catalyst layers utilised some of the highest loadings at $4 \mathrm{mg}_{\mathrm{Pt}} \mathrm{cm}^{-2}$. The lowest loading for catalyst powder was found from inkjet printing, ranging from $0.021 \mathrm{mg} \mathrm{pt}^{-2}$ to 0.5 $\mathrm{mgPt} \mathrm{cm}{ }^{-2}$. Vapour based methods showed much better loadings, from $5 \mu \mathrm{g}_{\mathrm{Pt}} \mathrm{cm}^{-2}$ for RF and Helicon RF sputtering techniques to $0.4 \mathrm{mg}_{\mathrm{Pt}} \mathrm{cm}^{-2}$ for a basic plasma sputtering method. For electrical processes, catalyst loadings ranged from as low as $0.877 \mu \mathrm{g}_{\mathrm{Pt}} \mathrm{cm}^{-2}$ for electrospinning to $0.3 \mathrm{mg}_{\mathrm{Pt}} \mathrm{cm}^{-2}$ for electrospray. Only once source gave any indication of the loading for the ultrasonic spray technique, at $50 \mu \mathrm{g}_{\mathrm{Pt}} \mathrm{cm}^{-2}$. There was 
no literature that gave any indication of the loading for the nanostructured catalyst layer method. Table 2 indicates the catalyst loadings for the methods that had published information about their loadings.

Table 2: Catalyst Loadings of Main Methods for MEA Manufacture

\begin{tabular}{|c|c|c|c|}
\hline & Method & Process & Loading (mg $\mathrm{mt}_{\mathrm{Pt}} \mathrm{cm}^{-2}$ ) \\
\hline \multirow[t]{2}{*}{1} & \multirow[t]{2}{*}{$\begin{array}{l}\text { Catalyst powder- } \\
\text { based methods }\end{array}$} & $\begin{array}{c}\text { Teflon bonded catalyst } \\
\text { layers }\end{array}$ & 4 \\
\hline & & Inkjet printing & $0.021-0.5$ \\
\hline \multirow[t]{7}{*}{2} & \multirow{7}{*}{$\begin{array}{l}\text { Vapour based } \\
\text { methods }\end{array}$} & Plasma sputtering & 0.4 \\
\hline & & DC Plasma sputtering & $0.04-0.1$ \\
\hline & & VHF Sputtering & 0.08 \\
\hline & & RF Sputtering & 0.005 \\
\hline & & $\begin{array}{c}\text { Transformer coupled RF } \\
\text { Sputtering }\end{array}$ & $\begin{array}{c}0.001\left({ }^{*} \text { mixed with }\right. \\
\mathrm{Pd})\end{array}$ \\
\hline & & Helicon RF Sputtering & 0.005 \\
\hline & & $\begin{array}{c}\text { Ion beam in catalyst } \\
\text { deposition }\end{array}$ & 0.017 \\
\hline \multirow[t]{3}{*}{3} & \multirow[t]{3}{*}{ Electrical Processes } & $\begin{array}{c}\text { Pulsed } \\
\text { electrodeposition }\end{array}$ & 0.025 \\
\hline & & Electrospray & $0.01-0.3$ \\
\hline & & Electrospinning & $\begin{array}{c}0.877 \mu g_{\mathrm{Pt}} \mathrm{cm}^{-2}-0.1 \\
\mathrm{mg}_{\mathrm{Pt}} \mathrm{cm}^{-2}\end{array}$ \\
\hline 4 & Ultrasonic spray & Ultrasonic spray & 0.05 \\
\hline 5 & $\begin{array}{l}\text { Nanostructured } \\
\text { catalyst layers }\end{array}$ & $\begin{array}{c}\text { Nanostructured catalyst } \\
\text { layers }\end{array}$ & Unknown \\
\hline
\end{tabular}

In addition to lowering the catalyst loading, which will help to significant reduce costs in any scale up context, some of these methods show great promise in durability and performance and offer great potential for the future of fuel cell manufacturing.

\section{ACKNOWLEDGMENT}

The authors would like to acknowledge the WMG High Value Manufacturing Catapult at the University of Warwick, Coventry, UK and the Richard G. Lugar Center for Renewable Energy at Indiana University Purdue University, Indianapolis, USA.

\section{FUNDING}

This paper was funded by the High Value Manufacturing Catapult and partially funded by the US Army Office. 
Journal of Fuel Cell Science and Technology

\section{REFERENCES}

[1] S. Giddey, S. P. S. Badwal, A. Kulkarni, and C. Munnings, "A comprehensive review of direct carbon fuel cell technology," Prog. Energy Combust. Sci., vol. 38, no. 3, pp. 360-399, 2012.

[2] Y. Wang, K. S. Chen, J. Mishler, S. C. Cho, and X. C. Adroher, "A review of polymer electrolyte membrane fuel cells: Technology, applications, and needs on fundamental research," Appl. Energy, vol. 88, no. 4, pp. 9811007, Apr. 2011.

[3] M. Z. F. Kamarudin, S. K. Kamarudin, M. S. Masdar, and W. R. W. Daud, "Review: Direct ethanol fuel cells," Int. J. Hydrogen Energy, pp. 1-16, Sep. 2012.

[4] a. Kirubakaran, S. Jain, and R. K. Nema, "A review on fuel cell technologies and power electronic interface," Renew. Sustain. Energy Rev., vol. 13, no. 9, pp. 2430-2440, Dec. 2009.

[5] J. Wing, "Why Fuel Cells for Telecoms Backup is a Good Call," Fuel Cell Today, Jun-2013.

[6] J. W. Kim, "Recent Achievements in Hydrogen and Fuel Cells in Korea," in International Hydrogen Energy Development Forum, 2013.

[7] "Pathways to Commercial Success : Technologies and Products Supported by the Fuel Cell Technologies Program," 2012.

[8] B. D. James and A. B. Spisak, "Mass Production Cost Estimation of Direct H2 PEM Fuel Cell Systems for Transportation Applications: 2012 Update," 2012.

[9] US Dept of Energy and National InstituteOf Standards, "Manufacturing for the Hydrogen Economy Manufacturing Research \& Development of PEM Fuel Cell Systems for Transportation Applications," 2005.

[10] V. Mehta and J. S. Cooper, "Review and analysis of PEM fuel cell design and manufacturing," J. Power Sources, vol. 114, no. 1, pp. 32-53, Feb. 2003.

[11] S. Litster and G. McLean, "PEM fuel cell electrodes," J. Power Sources, vol. 130, no. 1-2, pp. 61-76, May 2004.

[12] J.-H. Wee, K.-Y. Lee, and S. H. Kim, "Fabrication methods for low-Pt-loading electrocatalysts in proton exchange membrane fuel cell systems," J. Power Sources, vol. 165, no. 2, pp. 667-677, Mar. 2007.

[13] S. Srinivasan, "Advances in solid polymer electrolyte fuel cell technology with low platinum loading electrodes.," J. Power Sources, vol. 22, no. 3, pp. 359-375, 1988.

[14] M. S. Wilson, "High Performance Catalyzed Membranes of Ultra-low Pt Loadings for Polymer Electrolyte Fuel Cells," J. Electrochem. Soc., vol. 139, no. 2, p. L28, 1992.

[15] S. Q. Song, Z. X. Liang, W. J. Zhou, G. Q. Sun, Q. Xin, V. Stergiopoulos, and P. Tsiakaras, "Direct methanol fuel cells: The effect of electrode fabrication procedure on MEAs structural properties and cell performance," $J$. Power Sources, vol. 145, no. 2, pp. 495-501, Aug. 2005.

[16] H. Tang, S. Wang, M. Pan, S. P. Jiang, and Y. Ruan, "Performance of direct methanol fuel cells prepared by hot-pressed MEA and catalyst-coated membrane (CCM)," Electrochim. Acta, vol. 52, no. 11, pp. 3714-3718, Mar. 2007. 
Journal of Fuel Cell Science and Technology

[17] J. Zhang, G. Yin, Z. Wang, and Y. Shao, "Effects of MEA preparation on the performance of a direct methanol fuel cell," J. Power Sources, vol. 160, no. 2, pp. 1035-1040, Oct. 2006.

[18] C. Hsu, "An innovative process for PEMFC electrodes using the expansion of Nafion film," J. Power Sources, vol. 115, no. 2, pp. 268-273, Apr. 2003.

[19] M. S. Wilson and S. Gottesfeld, "Thin-film catalyst layers for polymer electrolyte fuel cell electrodes," J. Appl. Electrochem., vol. 22, pp. 1-7, 1992.

[20] M. S. Wilson, J. A. Valerio, and S. Gottesfeld, "Low Platinum Loading Electrodes for Polymer Electrolyte Fuel Cells Fabricated using Thermoplastic lonomers," Electrochim. Acta, vol. 40, no. 3, pp. 355-363, 1995.

[21] J. H. Cho, J. M. Kim, J. Prabhuram, S. Y. Hwang, D. J. Ahn, H. Y. Ha, and S.-K. Kim, "Fabrication and evaluation of membrane electrode assemblies by low-temperature decal methods for direct methanol fuel cells," J. Power Sources, vol. 187, no. 2, pp. 378-386, Feb. 2009.

[22] K.-H. Kim, K.-Y. Lee, H.-J. Kim, E. Cho, S.-Y. Lee, T.-H. Lim, S. P. Yoon, I. C. Hwang, and J. H. Jang, "The effects of Nafion ${ }^{\circledR}$ ionomer content in PEMFC MEAs prepared by a catalyst-coated membrane (CCM) spraying method," Int. J. Hydrogen Energy, vol. 35, no. 5, pp. 2119-2126, Mar. 2010.

[23] S. Song, G. Wang, W. Zhou, X. Zhao, G. Sun, Q. Xin, S. Kontou, and P. Tsiakaras, "The effect of the MEA preparation procedure on both ethanol crossover and DEFC performance," J. Power Sources, vol. 140, no. 1, pp. 103-110, Jan. 2005.

[24] C. S. Kim, Y. G. Chun, D. H. Peck, and D. R. Shin, "A Novel Process to Fabricate Membrane Electrode Assemblies for Proton Exchange Membrane Fuel Cells," Int. J. Hydrogen Energy, vol. 23, no. 11, pp. 10451048, 1998

[25] Y.-G. Chun, C.-S. Kim, D.-H. Peck, and D.-R. Shin, "Performance of a polymer electrolyte membrane fuel cell with thin film catalyst electrodes," J. Power Sources, vol. 71, no. 1-2, pp. 174-178, Mar. 1998.

[26] J. W. Ihm, H. Ryu, J. S. Bae, W. K. Choo, and D. K. Choi, "High performance of electrode with low Pt loading prepared by simplified direct screen printing process in PEM fuel cells," J. Mater. Sci., vol. 39, no. 14, pp. 4647-4649, Jul. 2004.

[27] N. Rajalakshmi and K. S. Dhathathreyan, "Catalyst layer in PEMFC electrodes - Fabrication, characterisation and analysis," Chem. Eng. J., vol. 129, no. 1-3, pp. 31-40, May 2007.

[28] K. Bolwin, E. Giilzow, D. Bevers, and W. Schnumberger, "Preparation of porous electrodes and laminated electrode- membrane structures for polymer electrolyte fuel cells ( PEFC )," Solid State lonics, vol. 2738, no. 95, pp. 324-330, 1995.

[29] D. Bevers, N. Wagner, and M. Von Bradke, "Innovative Production Procedure for Low Cost PEFC Electrodes and Electrode/Membrane Structures," Int. J. Hydrogen Energy, vol. 23, no. 1, pp. 57-63, 1998.

[30] E. Gülzow, M. Schulze, N. Wagner, T. Kaz, R. Reissner, G. Steinhilber, and a Schneider, "Dry layer preparation and characterisation of polymer electrolyte fuel cell components," J. Power Sources, vol. 86, no. 1-2, pp. 352-362, Mar. 2000.

[31] E. Gülzow and T. Kaz, "New results of PEFC electrodes produced by the DLR dry preparation technique," J. Power Sources, vol. 106, pp. 122-125, 2002. 
Journal of Fuel Cell Science and Technology

[32] A. P. Saab, F. H. Garzon, and T. a. Zawodzinski, "Determination of Ionic and Electronic Resistivities in Carbon/Polyelectrolyte Fuel-Cell Composite Electrodes," J. Electrochem. Soc., vol. 149, no. 12, p. A1541, 2002.

[33] G. Bender, T. a Zawodzinski, and A. P. Saab, "Fabrication of high precision PEFC membrane electrode assemblies," J. Power Sources, vol. 124, no. 1, pp. 114-117, Oct. 2003.

[34] S. Towne, V. Viswanathan, J. Holbery, and P. Rieke, "Fabrication of polymer electrolyte membrane fuel cell MEAs utilizing inkjet print technology," J. Power Sources, vol. 171, no. 2, pp. 575-584, Sep. 2007.

[35] A. D. Taylor, E. Y. Kim, V. P. Humes, J. Kizuka, and L. T. Thompson, "Inkjet printing of carbon supported platinum 3-D catalyst layers for use in fuel cells," J. Power Sources, vol. 171, no. 1, pp. 101-106, Sep. 2007.

[36] M. S. Saha, D. K. Paul, D. Malevich, B. A. Peppley, and K. Karan, "Preparation of Ultra-Thin Catalyst Layers by Piezo-electric Printer for PEMFCs Applications," ECS Trans., vol. 25, no. 1, pp. 2049-2059, 2009.

[37] D. Malevich, M. S. Saha, E. Halliop, B. A. Peppley, J. G. Pharoah, and K. Karan, "Performance Characteristics of PEFCs with Patterned Electrodes Prepared by Piezo-electric Printing," ECS Trans., vol. 50, no. 2, pp. 423-427, 2012.

[38] M. Yazdanpour, A. Esmaeilifar, and Soosan Rowshanzamir, "Effects of hot pressing conditions on the performance of Nafion membranes coated by ink-jet printing of Pt/MWCNTs electrocatalyst for PEMFCs," Int. J. Hydrogen Energy, vol. 37, pp. 11290-11298, 2012.

[39] S. D. Wu, C. P. Chou, R. G. Peng, C. H. Lee, and Y. Z. Wang, "A novel scrape-applied method for the manufacture of the membrane-electrode assembly of the fuel-cell system," Acta Mech. Sin., vol. 25, no. 6, pp. 831-837, May 2009.

[40] X. Ding, S. Didari, T. F. Fuller, and T. a. L. Harris, "Membrane Electrode Assembly Fabrication Process for Directly Coating Catalyzed Gas Diffusion Layers," J. Electrochem. Soc., vol. 159, no. 6, p. B746, 2012.

[41] J. O. Bockris, "Effect of a Finite-Contact-Angle Meniscus on Kinetics in Porous Electrode Systems," J. Chem. Phys., vol. 50, no. 3, p. 1307, 1969.

[42] M. F. Weber, S. Mamiche-Afara, M. J. Dignam, L. Pataki, and R. D. Venter, "Sputtered Fuel Cell Electrodes," J. Electrochem. Soc., vol. 86, no. June, pp. 1416-1419, 1987.

[43] J. A. Ticiauelli and C. R. Derouin, "valuation of plating in low catalyst loading electrodes to to attain high power densities in SPE fuel cells," vol. 251, pp. 275-295, 1988.

[44] S. Mukerjee, S. Srinivasan, and A. J. Appleby, "Effect of sputtered film of platinum on low platinum loading electrodes on electrode kinetics of oxygen reduction in proton exchange membrane fuel cells," Electrochim. Acta, vol. 38, no. 12, pp. 1661-1669, Aug. 1993.

[45] S. Hirano, J. Kim, and S. Srinivasan, "High performance proton exchange membrane fuel cells with sputterdeposited Pt layer electrodes," Electrochim. Acta, vol. 42, no. 96, pp. 1587-1593, 1997.

[46] S. Y. Cha and W. M. Lee, "Performance of Proton Exchange Membrane Fuel Cell Electrodes Prepared by Direct Deposition of Ultrathin Platinum on the Membrane Surface," vol. 146, no. 11, pp. 4055-4060, 1999.

[47] A. T. Haug, R. E. White, J. W. Weidner, W. Huang, S. Shi, T. Stoner, and N. Rana, "Increasing Proton Exchange Membrane Fuel Cell Catalyst Effectiveness Through Sputter Deposition," J. Electrochem. Soc., vol. 149, no. 3, p. A280, 2002. 
Journal of Fuel Cell Science and Technology

[48] A. T. Haug, R. E. White, J. W. Weidner, W. Huang, S. Shi, N. Rana, S. Grunow, T. C. Stoner, and A. E. Kaloyeros, "Using Sputter Deposition to Increase CO Tolerance in a Proton-Exchange Membrane Fuel Cell," J. Electrochem. Soc., vol. 149, no. 7, p. A868, 2002.

[49] R. O'Hayre, S.-J. Lee, S.-W. Cha, and F. . Prinz, "A sharp peak in the performance of sputtered platinum fuel cells at ultra-low platinum loading," J. Power Sources, vol. 109, no. 2, pp. 483-493, Jul. 2002.

[50] P. Brault, a Caillard, a L. Thomann, J. Mathias, C. Charles, R. W. Boswell, S. Escribano, J. Durand, and T. Sauvage, "Plasma sputtering deposition of platinum into porous fuel cell electrodes," J. Phys. D. Appl. Phys., vol. 37, no. 24, pp. 3419-3423, Dec. 2004.

[51] D. Gruber, N. Ponath, J. Müller, and F. Lindstaedt, "Sputter-deposited ultra-low catalyst loadings for PEM fuel cells," J. Power Sources, vol. 150, pp. 67-72, Oct. 2005.

[52] D. Gruber and J. Müller, "Enhancing PEM fuel cell performance by introducing additional thin layers to sputter-deposited Pt catalysts," J. Power Sources, vol. 171, no. 2, pp. 294-301, Sep. 2007.

[53] A. Caillard, P. Brault, J. Mathias, C. Charles, R. W. Boswell, and T. Sauvage, "Deposition and diffusion of platinum nanoparticles in porous carbon assisted by plasma sputtering," Surf. Coat. Technol., vol. 200, pp. 391-394, 2005.

[54] K.-L. Huang, Y.-C. Lai, and C.-H. Tsai, "Effects of sputtering parameters on the performance of electrodes fabricated for proton exchange membrane fuel cells," J. Power Sources, vol. 156, no. 2, pp. 224-231, Jun. 2006.

[55] H. Rabat and P. Brault, "Plasma Sputtering Deposition of PEMFC Porous Carbon Platinum Electrodes," Fuel Cells, vol. 8, no. 2, pp. 81-86, Apr. 2008.

[56] M. Mougenot, a. Caillard, P. Brault, S. Baranton, and C. Coutanceau, "High Performance plasma sputtered PdPt fuel cell electrodes with ultra low loading," Int. J. Hydrogen Energy, vol. 36, no. 14, pp. 8429-8434, Jul. 2011.

[57] C.-H. Wan, M.-T. Lin, Q.-H. Zhuang, and C.-H. Lin, "Preparation and performance of a novel MEA with multi catalyst layer structure for PEFC by magnetron sputter deposition technique," Surf. Coat. Technol., vol. 201, pp. 214-222, 2006.

[58] S. J. Yoo, Y.-H. Cho, H.-S. Park, J. K. Lee, and Y.-E. Sung, "High utilization of Pt nanocatalysts fabricated using a high-pressure sputtering technique," J. Power Sources, vol. 178, no. 2, pp. 547-553, Apr. 2008.

[59] H.-T. Kim, J.-K. Lee, and J. Kim, "Platinum-sputtered electrode based on blend of carbon nanotubes and carbon black for polymer electrolyte fuel cell," J. Power Sources, vol. 180, no. 1, pp. 191-194, May 2008.

[60] M. Cavarroc, a. Ennadjaoui, M. Mougenot, P. Brault, R. Escalier, Y. Tessier, J. Durand, S. Roualdès, T. Sauvage, and C. Coutanceau, "Performance of plasma sputtered fuel cell electrodes with ultra-low Pt loadings," Electrochem. commun., vol. 11, no. 4, pp. 859-861, Apr. 2009.

[61] S. K. Natarajan and J. Hamelin, "High-performance anode for Polymer Electrolyte Membrane Fuel Cells by multiple-layer Pt sputter deposition,” J. Power Sources, vol. 195, no. 22, pp. 7574-7577, Nov. 2010.

[62] T. Nakakubo, M. Shibata, and K. Yasuda, "Membrane Electrode Assembly for Proton Exchange Membrane Fuel Cells Prepared by Sputter Deposition in Air and Transfer Method," J. Electrochem. Soc., vol. 152, no. 12, p. A2316, 2005. 
Journal of Fuel Cell Science and Technology

[63] A. Caillard, C. Charles, R. Boswell, and P. Brault, "Integrated plasma synthesis of efficient catalytic nanostructures for fuel cell electrodes," Nanotechnology, vol. 18, no. 30, p. 305603, Aug. 2007.

[64] A. Caillard, C. Charles, R. W. Boswell, and P. Brault, "Synthesis of Carbon Nanofibers and Microsystems by Combining Low-Pressure Helicon Plasma Techniques," vol. 36, no. 4, pp. 882-883, 2008.

[65] a Caillard, C. Charles, D. Ramdutt, R. Boswell, and P. Brault, "Effect of Nafion and platinum content in a catalyst layer processed in a radio frequency helicon plasma system," J. Phys. D. Appl. Phys., vol. 42, no. 4, p. 045207, Feb. 2009.

[66] G. K. Wolf and K. Zucholl, "Ion Implanted Catalysts for Fuel Cell Reactions," Nucl. Instruments Methods, vol. 210, pp. 835-840, 1983.

[67] N. Ramaswamy, T. M. Arruda, W. Wen, N. Hakim, M. Saha, a. Gullá, and S. Mukerjee, "Enhanced activity and interfacial durability study of ultra low Pt based electrocatalysts prepared by ion beam assisted deposition (IBAD) method," Electrochim. Acta, vol. 54, no. 26, pp. 6756-6766, Nov. 2009.

[68] A. F. Gullá, M. S. Saha, R. J. Allen, and S. Mukerjee, "Dual Ion-Beam-Assisted Deposition as a Method to Obtain Low Loading-High Performance Electrodes for PEMFCs," Electrochem. Solid-State Lett., vol. 8, no. 10, p. A504, 2005.

[69] A. F. Gullá, M. S. Saha, R. J. Allen, and S. Mukerjee, "Toward Improving the Performance of PEM Fuel Cell by Using Mix Metal Electrodes Prepared by Dual IBAD," J. Electrochem. Soc., vol. 153, no. 2, p. A366, 2006.

[70] M. S. Saha, A. F. Gullá, R. J. Allen, and S. Mukerjee, "High performance polymer electrolyte fuel cells with ultra-low Pt loading electrodes prepared by dual ion-beam assisted deposition," Electrochim. Acta, vol. 51, no. 22, pp. 4680-4692, Jun. 2006.

[71] N. Cunningham, E. Irissou, M. Lefèvre, M.-C. Denis, D. Guay, and J.-P. Dodelet, "PEMFC Anode with Very Low Pt Loadings Using Pulsed Laser Deposition," Electrochem. Solid-State Lett., vol. 6, no. 7, p. A125, 2003.

[72] A. M. Feltham, M. Spiro, I. Introduction, C. Efficiency, D. S. Pretreatment, A. D. Appearance, B. D. Growth, V. S. Area, A. E. Determination, C. Reproducibility, and R. P. Procedures, "PLATINIZED PLATINUM ELECTRODES," vol. 1970 , no. $1895,1970$.

[73] K. Itaya, H. Takahashi, and I. Uchida, "Electrodepostion of Pt ultramicroparticles in Nafion films on glassy carbon electrodes," J. Electroanal. Chem., vol. 208, no. 1986, pp. 373-382, 1986.

[74] E. J. Taylor, E. B. Anderson, and N. R. K. Vilambi, "Preparation of High-Platinum-Utilization Gas Diffusion Electrodes for Proton-Exchange-Membrane Fuel Cells," vol. 139, no. 5, pp. 45-46, 1992.

[75] M. W. Verbrugge, "Selective Electrodeposition of Catalyst within Membrane-Electrode Structures," J. Electrochem. Soc., vol. 141, no. 1, p. 46, 1994.

[76] S. D. Thompson, L. R. Jordan, and M. Forsyth, "Platinum electrodeposition for polymer electrolyte membrane fuel cells," Electrochim. Acta, vol. 46, no. 10-11, pp. 1657-1663, Mar. 2001.

[77] K. H. Choi, H. S. Kim, and T. H. Lee, "Electrode fabrication for proton exchange membrane fuel cells by pulse electrodeposition," J. Power Sources, vol. 75, no. 2, pp. 230-235, Oct. 1998.

[78] H. Kim and B. N. Popov, "Development of Novel Method for Preparation of PEMFC Electrodes," Electrochem. Solid-State Lett., vol. 7, no. 4, p. A71, 2004. 
Journal of Fuel Cell Science and Technology

[79] H. Kim, N. P. Subramanian, and B. N. Popov, "Preparation of PEM fuel cell electrodes using pulse electrodeposition," J. Power Sources, vol. 138, no. 1-2, pp. 14-24, Nov. 2004.

[80] J. Lee, J. Seo, K. Han, and H. Kim, "Preparation of low Pt loading electrodes on Nafion (Na+)-bonded carbon layer with galvanostatic pulses for PEMFC application," J. Power Sources, vol. 163, no. 1, pp. 349-356, Dec. 2006.

[81] S. M. Ayyadurai, Y.-S. Choi, P. Ganesan, S. P. Kumaraguru, and B. N. Popov, "Novel PEMFC Cathodes Prepared by Pulse Deposition," J. Electrochem. Soc., vol. 154, no. 10, p. B1063, 2007.

[82] N. Rajalakshmi and K. Dhathathreyan, "Nanostructured platinum catalyst layer prepared by pulsed electrodeposition for use in PEM fuel cells," Int. J. Hydrogen Energy, vol. 33, no. 20, pp. 5672-5677, Oct. 2008.

[83] a. J. Martín, a. M. Chaparro, B. Gallardo, M. a. Folgado, and L. Daza, “Characterization and single cell testing of Pt/C electrodes prepared by electrodeposition," J. Power Sources, vol. 192, no. 1, pp. 14-20, Jul. 2009.

[84] Z. D. Wei, S. G. Chen, Y. Liu, C. X. Sun, Z. G. Shao, and P. K. Shen, "Electrodepositing Pt by Modulated Pulse Current on a Nafion-Bonded Carbon Substrate as an Electrode for PEMFC," J. Phys. Chem. C, vol. 111, no. 42, pp. 15456-15463, Oct. 2007.

[85] B. G. Pollet, "The Use of Ultrasound (20 kHz) as a Novel Method for Preparing Proton Exchange Membrane Fuel Cell Electrodes," ECS Trans., vol. 16, no. 2, pp. 2031-2041, 2008.

[86] B. G. Pollet, "A novel method for preparing PEMFC electrodes by the ultrasonic and sonoelectrochemical techniques," Electrochem. commun., vol. 11, no. 7, pp. 1445-1448, Jul. 2009.

[87] H. Morikawa, N. Tsuihiji, T. Mitsui, and K. Kanamura, "Preparation of Membrane Electrode Assembly for Fuel Cell by Using Electrophoretic Deposition Process," J. Electrochem. Soc., vol. 151, no. 10, p. A1733, 2004.

[88] H. Munakata, T. Ishida, and K. Kanamura, "Preparation of Nano-Structured Catalyst Layers on Nafion ${ }^{\circledR}$ Membrane by Electrophoretic Deposition," ECS Trans., vol. 3, no. 1, pp. 329-335, 2006.

[89] H. Munakata, T. Ishida, and K. Kanamura, "Electrophoretic Deposition for Nanostructural Design of Catalyst Layers on Nafion Membrane," J. Electrochem. Soc., vol. 154, no. 12, p. B1368, 2007.

[90] Y.-T. Yu, J.-C. Song, J.-H. Kim, Y.-S. Kim, and H.-G. Lee, "Nano-architecture platinum catalyst layer prepared by electrophoresis deposition for PEM fuel cells," J. Solid State Electrochem., vol. 16, no. 4, pp. 1377-1381, Aug. 2011.

[91] G. Adilbish, J.-W. Kim, H.-G. Lee, and Y.-T. Yu, "Effect of the deposition time on the electrocatalytic activity of $\mathrm{Pt} / \mathrm{C}$ catalyst electrodes prepared by pulsed electrophoresis deposition method," Int. J. Hydrogen Energy, vol. 38, no. 9, pp. 3606-3613, Mar. 2013.

[92] C. Felix, T.-C. Jao, S. Pasupathi, and B. G. Pollet, “Optimisation of electrophoretic deposition parameters for gas diffusion electrodes in high temperature polymer electrolyte membrane fuel cells," J. Power Sources, vol. 243, pp. 40-47, Dec. 2013.

[93] O. a. Baturina and G. E. Wnek, "Characterization of Proton Exchange Membrane Fuel Cells with Catalyst Layers Obtained by Electrospraying," Electrochem. Solid-State Lett., vol. 8, no. 6, p. A267, 2005.

[94] R. Benítez, J. Soler, and L. Daza, "Novel method for preparation of PEMFC electrodes by the electrospray technique," J. Power Sources, vol. 151, pp. 108-113, Oct. 2005. 
Journal of Fuel Cell Science and Technology

[95] a. M. Chaparro, R. Benítez, L. Gubler, G. G. Scherer, and L. Daza, "Study of membrane electrode assemblies for PEMFC, with cathodes prepared by the electrospray method," J. Power Sources, vol. 169, no. 1, pp. 7784, Jun. 2007.

[96] S. Martin, P. L. Garcia-Ybarra, and J. L. Castillo, "Electrospray deposition of catalyst layers with ultra-low Pt loadings for PEM fuel cells cathodes," J. Power Sources, vol. 195, no. 9, pp. 2443-2449, May 2010.

[97] S. Martin, P. L. Garcia-Ybarra, and J. L. Castillo, "High platinum utilization in ultra-low Pt loaded PEM fuel cell cathodes prepared by electrospraying," Int. J. Hydrogen Energy, vol. 35, no. 19, pp. 10446-10451, Oct. 2010.

[98] S. Martin, B. Martinez-Vazquez, P. L. Garcia-Ybarra, and J. L. Castillo, "Peak utilization of catalyst with ultralow Pt loaded PEM fuel cell electrodes prepared by the electrospray method," J. Power Sources, vol. 229, pp. 179-184, May 2013.

[99] W. Zhang, M. W. Brodt, and P. N. Pintauro, "Nanofiber Cathodes for Low and High Humidity Hydrogen Fuel Cell Operation," ECS Trans., vol. 41, no. 1, pp. 891-899, 2011.

[100] W. Zhang and P. N. Pintauro, "High-performance nanofiber fuel cell electrodes.," ChemSusChem, vol. 4, no. 12, pp. 1753-7, Dec. 2011.

[101] J. Sightler, E. Mcpherson, W. Rigdon, and X. Huang, "Application of Electrospinning Technique in the Fabrication of Catalyst Layer of Membrane Electrode Assemblies," ECS Trans., vol. 50, no. 2, pp. 1445-1451, 2012.

[102] M. Brodt, R. Wycisk, and P. N. Pintauro, "Nanofiber Electrodes with Low Platinum Loading for High Power Hydrogen/Air PEM Fuel Cells," J. Electrochem. Soc., vol. 160, no. 8, pp. F744-F749, Apr. 2013.

[103] B. G. Pollet, "The use of ultrasound for the fabrication of fuel cell materials," Int. J. Hydrogen Energy, vol. 35, no. 21, pp. 11986-12004, Nov. 2010.

[104] B. Millington, V. Whipple, and B. G. Pollet, "A novel method for preparing proton exchange membrane fuel cell electrodes by the ultrasonic-spray technique," J. Power Sources, vol. 196, no. 20, pp. 8500-8508, Oct. 2011.

[105] X. Huang, W. A. Rigdon, J. Neutzler, D. Larrabee, and J. Sightler, "High Performance Membrane Electrode Assembly Fabricated by Ultrasonic Spray Technique," ECS Trans., vol. 41, no. 1, pp. 901-907, 2011.

[106] T.-H. Huang, H.-L. Shen, T.-C. Jao, F.-B. Weng, and A. Su, "Ultra-low Pt loading for proton exchange membrane fuel cells by catalyst coating technique with ultrasonic spray coating machine," Int. J. Hydrogen Energy, vol. 37, no. 18, pp. 13872-13879, Sep. 2012.

[107] E. Middelman, "Improved PEM fuel cell electrodes by controlled self-assembly," Fuel Cells Bulletin, pp. 9-12, Nov-2002.

[108] A. M. Kannan, V. P. Veedu, L. Munukutla, and M. N. Ghasemi-Nejhad, "Nanostructured Gas Diffusion and Catalyst Layers for Proton Exchange Membrane Fuel Cells," Electrochem. Solid-State Lett., vol. 10, no. 3, p. B47, 2007.

[109] M. Michel, a. Taylor, R. Sekol, P. Podsiadlo, P. Ho, N. Kotov, and L. Thompson, "High-Performance Nanostructured Membrane Electrode Assemblies for Fuel Cells Made by Layer-By-Layer Assembly of Carbon Nanocolloids," Adv. Mater., vol. 19, no. 22, pp. 3859-3864, Nov. 2007.

[110] L. Wang, S. Guo, J. Zhai, and S. Dong, "Facile Synthesis of Platinum Nanoelectrocatalyst with Urchinlike Morphology," J. Phys. Chem. C, vol. 112, no. 35, pp. 13372-13377, Sep. 2008. 
Journal of Fuel Cell Science and Technology

[111] R. a. Hackendorn and A. V. Virkar, "Synthesis of platinum nanoclusters and electrochemical investigation of their stability," J. Power Sources, vol. 240, pp. 618-629, Oct. 2013.

[112] E. P. Lee, Z. Peng, D. M. Cate, H. Yang, C. T. Campbell, and Y. Xia, "Growing Pt nanowires as a densely packed array on metal gauze.," J. Am. Chem. Soc., vol. 129, no. 35, pp. 10634-5, Sep. 2007.

[113] S. Sun, F. Jaouen, and J.-P. Dodelet, "Controlled Growth of Pt Nanowires on Carbon Nanospheres and Their Enhanced Performance as Electrocatalysts in PEM Fuel Cells," Adv. Mater., vol. 20, no. 20, pp. 3900-3904, Oct. 2008.

[114] S. Du, "A Facile Route for Polymer Electrolyte Membrane Fuel Cell Electrodes with in situ Grown Pt Nanowires," J. Power Sources, vol. 195, no. 1, pp. 289-292, Jan. 2010.

[115] S. H. Sun, D. Q. Yang, D. Villers, G. X. Zhang, E. Sacher, and J. P. Dodelet, "Template- and Surfactant-free Room Temperature Synthesis of Self-Assembled 3D Pt Nanoflowers from Single-Crystal Nanowires," Adv. Mater., vol. 20, no. 3, pp. 571-574, Feb. 2008.

[116] J. Chen, B. Lim, E. P. Lee, and Y. Xia, "Shape-controlled synthesis of platinum nanocrystals for catalytic and electrocatalytic applications," Nano Today, vol. 4, no. 1, pp. 81-95, Feb. 2009. 